\section{Response to: 'Overlap of systemic lupus erythematosus and myositis is rare in anti-Ku antibody-positive patients' by Ogawa- Momohara et al}

We thank Ogawa-Momohara et al for their comment ${ }^{1}$ on our work in which we identified that anti-Ku patients with elevated serum creatine kinase (elevated CK) are at risk of interstitial lung disease (ILD), whereas anti-Ku patients with anti-double-strand DNA (dsDNA) antibodies frequently have systemic lupus erythematosus (SLE) and are at risk of glomerulonephritis. ${ }^{2}$

The data reported by Ogawa-Momohara et al importantly complete our results since none of our anti-Ku patients had an Asian origin. Ogawa-Momohara et al retrospectively screened sera from 600 Japanese patients with connective tissue diseases and found 10 anti-Ku-positive patients.

Their data confirm that anti-Ku patients with elevated CK are at risk of ILD and rarely overlap with anti-Ku patients with SLE who are at risk of glomerulonephritis. Among their five antiKu-positive patients with elevated CK, three had ILD and none had glomerulonephritis. By contrast, among the three patients diagnosed with SLE, none had increased CK; only one had ILD; and all had nephritis.

Yet, in contrast with our cohort, when detected, anti-dsDNA antibodies were systematically found in patients with elevated CK $(n=3 / 5)$, while none of their anti-Ku patients with SLE tested positive for anti-dsDNA. This finding is in contrast to several previous non-Asian series in which anti-dsDNA antibodies were more frequently ${ }^{3-5}$ or even exclusively ${ }^{6}$ detected in anti-Ku patients with SLE as compared with anti-Ku patients with other connective tissue diseases.

As pointed by Ogawa-Momohara et al, this may indicate that genetic and/or environmental backgrounds may shape the antidsDNA profile of anti-Ku patients, although results may have also been influenced by detection methods used and/or delay between treatment onset and serum sampling.

In conclusion, as pointed by Ogawa-Momohara et al, the patients' geographical origin must be taken into consideration when describing connective tissue diseases. In this regard, the data provided by Ogawa-Momohara et al represent an important addition to our own findings by shedding light on the spectrum of anti-Ku-related disease in Asian patients.

\footnotetext{
Lionel Spielmann $\odot{ }^{1}{ }^{1}$ Benoit Nespola, ${ }^{2}$ Alain Meyer ${ }^{3,4,5}$

${ }^{1}$ Service de Rhumatologie, Hôpitaux Civils de Colmar, Colmar, France

2Laboratoire d'immunologie, Hôpitaux Universitaires de Strasbourg, Strasbourg,

France
}

${ }^{3}$ Exploration Fonctionnelle Musculaire, Hôpitaux Universitaires de Strasbourg de Strasbourg, Strasbourg, France

${ }^{4}$ Centre National de Référence des Maladies Auto-Immunes Systémiques Rares de l'Est et du Sud-Ouest, Service de rhumatologie, Hôpitaux Universitaires de Strasbourg, Strasbourg, France

${ }^{5}$ Fédération de médecine translationnelle de Strasbourg, FRU 6702, Hôpitaux Universitaires de Strasbourg, Strasbourg, France

Correspondence to Dr Lionel Spielmann, Service de Rhumatologie, Hospices civils de Colmar, Colmar, Alsace (Région), France; lionel.spielmann@ch-colmar.fr

Handling editor Josef $S$ Smolen

Contributors $L S, A M$ and BN contributed to the writing of the manuscript.

Funding The authors have not declared a specific grant for this research from any funding agency in the public, commercial or not-for-profit sectors.

Competing interests None declared.

Patient consent for publication Not required.

Provenance and peer review Commissioned; internally peer reviewed.

(c) Author(s) (or their employer(s)) 2019. No commercial re-use. See rights and permissions. Published by BMJ.

\section{Check for updates}

To cite Spielmann L, Nespola B, Meyer A. Ann Rheum Dis Epub ahead of print: [please include Day Month Year]. doi:10.1136/annrheumdis-2019-216413

Received 11 November 2019

Accepted 11 November 2019

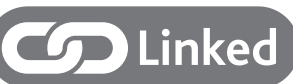

- http://dx.doi.org/10.1136/annrheumdis-2019-216375

Ann Rheum Dis 2019;0:1. doi:10.1136/annrheumdis-2019-216413

ORCID iD

Lionel Spielmann http://orcid.org/0000-0003-1057-6890

\section{REFERENCES}

1 Ogawa-Momohara M, Muro Y, Akiyama M. Overlap of systemic lupus erythematosus and myositis is rare in anti-Ku antibody-positive patients. Ann Rheum Dis 2019. doi:10.1136/annrheumdis-2019-216375. [Epub ahead of print: 11 Oct 2019].

2 Spielmann L, Nespola B, Séverac F, et al. Anti-Ku syndrome with elevated CK and antiKu syndrome with anti-dsDNA are two distinct entities with different outcomes. Ann Rheum Dis 2019;78:1101-6.

3 Cooley HM, Melny BJ, Gleeson R, et al. Clinical and serological associations of anti-Ku antibody. J Rheumatol 1999;26:563-7.

4 Rigolet A, Musset L, Dubourg 0, et al. Inflammatory myopathies with anti$\mathrm{Ku}$ antibodies: a prognosis dependent on associated lung disease. Medicine 2012;91:95-102.

5 Cavazzana I, Fredi M, Taraborelli M, et al. A subset of systemic sclerosis but not of systemic lupus erythematosus is defined by isolated anti-Ku autoantibodies. Clin Exp Rheumatol 2013;31:118-21.

6 Cavazzana I, Ceribelli A, Quinzanini M, et al. Prevalence and clinical associations of anti-Ku antibodies in systemic autoimmune diseases. Lupus 2008;17:727-32. 